IZA DP No. 5613

The Use of Welfare by Migrants in Italy

Michele Pellizzari

April 2011 


\title{
The Use of Welfare by Migrants in Italy
}

\author{
Michele Pellizzari \\ Bocconi University, \\ IGIER, fRDB and IZA
}

\section{Discussion Paper No. 5613 \\ April 2011}

\author{
IZA \\ P.O. Box 7240 \\ 53072 Bonn \\ Germany \\ Phone: +49-228-3894-0 \\ Fax: +49-228-3894-180 \\ E-mail: iza@iza.org
}

Any opinions expressed here are those of the author(s) and not those of IZA. Research published in this series may include views on policy, but the institute itself takes no institutional policy positions.

The Institute for the Study of Labor (IZA) in Bonn is a local and virtual international research center and a place of communication between science, politics and business. IZA is an independent nonprofit organization supported by Deutsche Post Foundation. The center is associated with the University of Bonn and offers a stimulating research environment through its international network, workshops and conferences, data service, project support, research visits and doctoral program. IZA engages in (i) original and internationally competitive research in all fields of labor economics, (ii) development of policy concepts, and (iii) dissemination of research results and concepts to the interested public.

IZA Discussion Papers often represent preliminary work and are circulated to encourage discussion. Citation of such a paper should account for its provisional character. A revised version may be available directly from the author. 
IZA Discussion Paper No. 5613

April 2011

\section{ABSTRACT}

\section{The Use of Welfare by Migrants in Italy ${ }^{*}$}

A large part of the Italian welfare system is designed and implemented at the very local level, leading to a high degree of heterogeneity in the type and the generosity of available programs across the country. As a consequence, studies of welfare use based on standard household surveys may fail to consider a large part of welfare recipients and provisions. In this paper I overcome such a problem by combining the analysis of welfare use in the Italian sample of the European Survey of Incomes and Living Conditions (EU-SILC) with the investigation of a new administrative archive that contains information on means tests certificates needed for applying to all kind of locally administered welfare programs. Results show that, without controlling for observable characteristics, migrants from outside the EU are more likely to receive or apply for welfare. Once individual and household characteristics are controlled for, such a residual welfare dependency is greatly reduced but does not disappear. Geographical location is a key factor, given that migrants tend to locate in the richest areas of the country, which also happen to be the ones where the local welfare is most generous.

JEL Classification: J61

Keywords: migration, welfare

Corresponding author:

Michele Pellizzari

Department of Economics

Bocconi University

via Roentgen 1

20136 Milan

Italy

E-mail: michele.pellizzari@unibocconi.it

\footnotetext{
* I gratefully acknowledge the financial support of IZA for this project. Davide Crapis provided outstanding research assistance.
} 


\section{Introduction}

Italy is one of the OECD countries that has experienced the largest increase in migration flows over the past decade. On average between 1998 and 2008 approximately 250,000 migrants arrived in Italy every year, approximately $0.5 \%$ of the resident population. The stock of foreigners in the country has consequently increased from $1.9 \%$ in 1998 to $5.8 \%$ in 2008 . These numbers compare to annual flows in the order of $0.15 \%$ to $0.28 \%$ of the resident population in countries like France, Germany and the UK over the same period. ${ }^{1}$

As a consequence, Italians are, among all European citizens, the ones whose opinions have become more and more anti-immigration over the past few years, as indicated by the European Social Surveys (Boeri, 2010; Boeri and Bruecker, 2005). Boeri (2010) shows that the main driver of such a deterioration in the Italians' views of immigration is the concern that migrants might represent a fiscal burden for the receiving country, mainly through the exploitation of its welfare state.

Whereas such a concern might be understandable in most pre-enlargement EU countries, like France, Germany or the UK, where the welfare system is relatively generous, it is surprising in Italy, a country where social expenditure is heavily concentrated on old age pensions, where there is no universal unemployment insurance and where the provision of income support programs is extremely limited. For example, Italy is the only country in the pre-enlargement EU-15, together with Greece, where a minimum income scheme does not exist (Monti and Pellizzari, 2010). Hence, there seems to be very little welfare to be exploited by migrants.

In fact, according to the summary measures of benefit generosity computed by the OECD, Italy consistently ranks among the least generous countries. Italy is among the very few countries where the OECD computes a replacement ratio equal to zero for long term unemployment (the others are Greece and Turkey). ${ }^{2}$ Furthermore, Italy ranks last in terms of summary generosity of benefits among all OECD countries for which such a statistics is available, with an average replacement ratio of $7 \%$ versus an OECD average of $53 \% .^{3}$

For these reasons, Italy seems to be a particularly interesting case to study. Unfortunately, data limitations and the peculiarities of the welfare arrangements in the country make it difficult to analyze the issue of migrants welfare dependency. For example, missing data on the crucial variables to identify migrants have severely limited the use of the European Community Household Panel (ECHP) to work on migration issues in Italy and to compare results with other countries (Boeri, 2010; Boeri and Bruecker, 2005; Brucker, Epstein, Saint-Paul, Venturini, and Zimmerman, 2002). Also, the Bank of Italy Survey of Household Income and Wealth, a commonly used dataset, only contains an indicator for whether the respondents' nationality is Italian. The replacement of the ECHP with the European Survey on Income and Living Conditions (EU-SILC) has improved things on this matter and the few studies that use this data source now report estimates for Italy, too (Boeri, 2010).

Above and beyond the data limitations, the high degree of fragmentation of the Italian welfare also complicates the analysis. In fact, other than pensions, unemployment benefits and a few family allowances that are administered centrally, anything else, from housing benefits or social housing to subsidized child care to income support, is fully delegated to local authorities, mainly municipalities.

\footnotetext{
${ }^{1}$ Only Spain has experienced migration flows that are comparable to Italy and, in some cases, even higher.

${ }^{2}$ The replacement ratio is computed as the ratio between the income a typical worker (various typologies are considered in the OECD statistics) earns from work and the amount of transfers such a typical worker would get when out of work.

${ }^{3}$ The summary generosity of benefits is computed as the average replacement ratio taken over several typologies of workers, income levels (median and $2 / 3$ of the median) and durations of unemployment.
} 
As a consequence, each of the over 8,000 Italian municipalities decides what programs to introduce and how to administer them. Furthermore, such decisions are often subject to budget constraints, so that many programs are withdrawn during the fiscal year when resources run out.

It is such a fragmentation, combined with the resource constraints, that might more likely explain the concerns of many Italians. Local welfare is more generous in the richest areas of the country, where local authorities can rely on more abundant financial resources. At the same time, such areas are also those where migrants are more likely to locate for the obvious reason that, typically, the relative demand for unskilled labour is higher. In rich areas Italians are relatively more educated, thus reducing the supply of native unskilled labour and, potentially, increasing the demand for personal services, like housekeeping and child/old-age care (Mazzolari and Ragusa, 2007). Hence, migrants cluster in rich areas and in unskilled occupations, where they earn lower wages than natives, who are concentrated in high-skill jobs. As a consequence, within geographical locations migrants' welfare dependency is relatively high.

In this paper I am able to overcome the data problems that have limited most previous research by combining two data sources, one of which has never been used for analyzing the use of welfare by migrants. ${ }^{4}$ First, for completeness and comparison with existing studies, I use the most recent wave of the EU-SILC, a European-wide household survey that has already been used to study residual welfare dependency (Boeri, 2010; Boeri and Bruecker, 2005; Brucker et al., 2002), to establish the main evidence on welfare use by migrants. Second, I complement the analysis of the EU-SILC with an investigation of an original administrative archive of means tests performed at all levels of the public administration to establish individual's and households' eligibility to all kinds of benefits, both in cash and in kind. The use of this new dataset allows me to capture the great heterogeneity of welfare programs across the country, although at the cost of looking at applications rather than actual recipiency. Nevertheless, it is only by using this alternative database that it is possible to capture the myriad of local welfare schemes that are unlikely to be covered in national-wide (or even European-wide) surveys, like the EU-SILC, that necessarily need to select a restricted set of standardized questions.

Two important areas of welfare provision are excluded from my analysis: the services offered through public education and public health. These are important issues that certainly deserve more attention by researchers but that cannot be analyzed thoroughly with my data.

The focus of the paper is mainly empirical. In fact, one can think of theoretical explanations for differences in welfare use by migrants and natives that go in both directions. On the one hand, language and other barriers to the circulation of information may discourage foreigners from applying for welfare assistance. On the other hand, networks of migrants have been documented to be extremely important in determining a wide array of economic outcomes and they may also facilitate the transmission of information about suitable welfare programs (Bauer, Epstein, and Gang, 2009; Carrington, Detragiache, and Vishwanath, 2001; Thomas Bauer, 2007; Winters, de Janvry, and Sadoulet, 2001). Take up rates may also vary between the native and the foreign populations (Borjas and Hilton, 1996; Borjas and Trejo, 1991; Hernanz, Malherbet, and Pellizzari, 2000). For example, to the extent that social stigma may explain the non take up of welfare benefits, one may think that such a mechanism is more important among natives, which should be characterized by a higher degree of heterogeneity. Migrants, being more homogeneous and all similarly likely to need assistance, may be less prone to suffer social stigma from their peers. On the other hand, one may also argue that the

\footnotetext{
${ }^{4}$ In fact, the only study I am aware of that uses this data source is Boeri, Dessy, Garibaldi, Monti, and Pellizzari (2007).
} 
desire to integrate may provide incentives to migrants to integrate "out of welfare" (Borjas and Trejo, 1991; Hansen and Lofstrom, 2003; Riphahn, 2004).

Perhaps, the only theoretical argument that unambiguously predicts higher welfare use by migrants is self-selection. A large parallel literature analyzes how the generosity of welfare affects the skill composition of the inflow of migrants (Borjas, 1999a; De Giorgi and Pellizzari, 2009; Enchautegui, 1997; Gelbach, 2004; Gramlich and Laren, 1984). The seminal theory developed in Borjas (1999a) and revisited by many other authors (De Giorgi and Pellizzari, 2009; Gelbach, 2004; Levine and Zimmerman, 1999; McKinnish, 2005, 2007; Meyer, 2000), suggests that, under the assumption that the welfare system of the receiving country benefits people at the lower end of the skill distribution, migrants moving from less to more generous countries (i.e. countries with more generous welfare benefits) should be negatively selected. Such a self selection process alone should be sufficient to explain a higher incidence of migrants among the welfare recipients. However, what is commonly referred to as residual welfare dependency is the fact that, even after controlling for all observable characteristics that might determine eligibility, migrants are still over-represented among welfare recipients. Hence, the explanatory power of the self-selection argument depends crucially on whether the selection is based on factors that are observable or unobservable in the particular data at hand.

The ambiguity of the theoretical arguments is mirrored in the mixture of the empirical findings one can find in the literature. Depending on the country, the data source, the type of migrants and the period examined results vary greatly. Borjas and Hilton (1996) and Borjas and Trejo (1991) find that migrants do receive both cash and non-cash benefits more often than US natives and that such a difference is more pronounced for recently arrived migrants. Hansen and Lofstrom (2003) analyze the same issue for Sweden and find that migrants do use welfare programs significantly more than natives and that such a difference remains even after controlling for observable characteristics. On the other side of the spectrum of possible results, Castronova, Kayser, Frick, and Wagner (2001) find that any additional welfare dependency of migrants in Germany disappears once conditioning on a rich enough set of observable characteristics, a result that is also confirmed by Riphahn (2004). Bratsberg, Raaum, and Roed (2007) show that migrants in Norway are net users of the welfare state, with adverse consequences on their labour market performance. A very different finding is documented in Barrett and McCarthy (2008) and Barrett and McCarthy (2007) for Ireland, where it is shown that, after controlling for a large set of observable characteristics, migrants use the welfare state significantly less than natives.

Contrary to some other studies, I will not try to answer the question of whether migrants are net contributors to the welfare state of the receiving country (Boeri, 2010; Dustmann, Frattini, and Halls, 2009; Rowthorn, 2008; Storesletten, 2000). Given the difficulties in addressing such an issue in a static framework and the arbitrariness of the assumptions needed to frame it dynamically, I prefer to concentrate on the simpler issue of welfare use.

The paper is organized as follows. In Section 2 I briefly outline the institutional peculiarities of the Italian welfare state. In Section 3 I describe the data sources that will be used in Section 4 to estimate the residual welfare dependency of migrants. Section 5 concludes.

\section{The Italian welfare state}

There are two features of the Italian welfare system that are worth emphasizing. First, it is disproportionately concentrated on pensions, which account for more than $46 \%$ of total social expenditure. 
Other expenditure items, like unemployment, family related benefits or income support, taken together only amount to $25 \%$. This compares to $32 \%$ spent on the same items in the average OECD country. ${ }^{5}$

Migrants' welfare dependency usually refers to non-pension benefits, as this kind of transfers can be usually received after a short period of residence in the country. Pension contributions, on the other hand, are often perceived as a deadweight loss for migrants, especially when they expect to leave the country before retirement (Dustmann, 1997). Hence, the particular distribution of social expenditure in Italy should make it a less attractive destination as compared to other European countries.

The second important feature of the Italian welfare is its geographical fragmentation. Only a handful of programs are offered by the central government, while the entire areas of education scholarships, social or subsidized housing and income support are fully delegated to the local authorities, mostly municipal governments. Hence, each of the over 8,000 Italian municipalities decides what programs to introduce and how to administer them. Furthermore, such decisions are often subject to budget constraints and need to be reconfirmed fiscal year after fiscal year. In case financial resources ran out before the following budget is approved the programs are terminated and some applicants, who would have otherwise been eligible, are denied access.

At the central level the National Social Security Administration (INPS) administers the unemployment benefits and family, sickness and maternity allowances. The main unemployment insurance program pays $50 \%$ to $60 \%$ of the last wage for 8 to 12 months, depending on age and contributory records. A minimum contribution period of 2 years is generally required for eligibility. This is the only program that is available to all workers. Other benefits are available to selected types of workers, mainly through a temporary employment reduction scheme (the so-called Cassa Integrazione Guadagni), which pays $80 \%$ of the hourly wage for each hour deducted from regular working time. Originally, such a program was available only to workers in large manufacturing firms but it has been extended to other categories over the years. Special schemes are available to particular types of workers (seasonal workers in agriculture, old workers, et.). Notice, that all these programs are insurance-based, although they do have some redistributive component through minimum and maximum payments. Overall, the coverage of unemployment benefits is extremely low. According to the 2008 labour force survey, less than $10 \%$ of currently unemployed workers was effectively receiving some kind of unemployment related benefit.

Sickness and maternity allowances are also insurance-based programmes and pay between $50 \%$ (sickness) and $80 \%$ (maternity) of the current wage for a maximum period of 180 days for sickness leave or 5 months for maternity.

Family benefits are also administered centrally. They are the only national purely non-contributory program in Italy and the most redistributive in the entire system (Baldini, Bosi, and Toso, 2000). ${ }^{6}$ They are means tested and the amount varies depending on the composition of the household. Eligibility is usually limited to household in the lower $30 \%$ of the income distribution and the amount of the transfer ranges from $4 \%$ to $12 \%$ of family income.

Other than these few programmes, everything else is left to the autonomous initiative of local governments. Although sometimes regions do legislate the introduction of some welfare scheme, it is normally the municipal governments that operate in this area. Such a situation generates a high degree of heterogeneity across the country, with some cities in the richest areas providing a long list

\footnotetext{
${ }^{5}$ OECD Social Expenditure Database.

${ }^{6}$ The other program with similar characteristics is the pensione sociale, social pension, essentially a minimum income scheme for people aged 65 and over.
} 
of programs for housing, education, child and old age care, general income support. In the poorest regions many cities do not offer any welfare.

Such a fragmentation makes it difficult for general surveys to set out questions that can effectively capture the variety of programs that are offered at the local level. For example, in some cases the municipal welfare office provides hot meals delivered at home for old people living alone or it offers occasional monetary support to pay expensive gas and electricity bills for poor families in particularly rigid winter seasons. I will be able to look at these programs, too, by focusing on a new administrative archive that contains a random sample of means tests. In fact, in order to apply for any means tested program one has to submit a form that certifies the household's financial situation, hence including income and wealth, equivalized by household size and composition. Such a certificate is issued by a special office at the Social Security Administration and the database that I use is a random extraction of records from their archive. More details about this data source are provided in Section 3.

Finally, it is worth mentioning that two other important areas of social expenditure for Italy are health and education, which are both offered by the government to all residents, including migrants, at no (or very small) direct cost. Both education and health are financed through general taxation. I will not touch upon these issues that have been overlooked by the entire literature and certainly deserve more careful research.

As far as eligibility is concerned, unemployment, sickness and maternity benefits are work-related schemes, which are associated with an employment relationship and are, therefore, available to all regular workers, although some provisions vary by type of contract (temporary vs. permanent, fulltime vs. part-time). Hence, legal immigrants who work regularly are eligible for these schemes. Family allowances are normally computed and paid at the moment of filing one's tax declaration, hence they are also available to legal migrants who do submit a tax form. Eligibility to all other locally administered welfare programs is often subject to a minimum period of residence in the territory of the municipality, both for Italians and for foreigners, although the requirement might be stricter for the latter.

As already mentioned, access to public education and health services is free of charge for all people regularly resident in Italy. Moreover, even the children of illegal migrants are required to comply with compulsory schooling and cannot be refused a place in public schools (even beyond compulsory schooling grades). Generally, the national health system covers only legal migrants but access to emergency rooms in all public hospitals is open to anyone, thus including illegal migrants who do not even need to provide personal documents for identification. ${ }^{7}$

\section{Data}

The most common dataset that is currently used to study the use of welfare in most European countries, and in Italy in particular, is the European Survey of Incomes and Living Conditions or EU-SILC (Boeri, 2010; Brucker et al., 2002). This is a collection of country specific samples of households, selected according to the same statistical procedures and administered the same questionnaires, merely translated in the local language. Hence, one important advantage of the EU-SILC is the high level of cross-country comparability (an advantage that I will not exploit here). The EU-SILC also has a longitudinal component, although the time coverage is still relatively limited, from 2004 to 2006 at

\footnotetext{
${ }^{7}$ In 2009 a hot public debate was generated by the proposal put forward by some politicians to require doctors to report to the police those patients who could not be identified. Eventually the proposal was withdrawn.
} 
yearly frequency. In the analysis of this paper I limit my attention to the most recent cross-section of 2007.

The Italian sample of the EU-SILC covers over approximately 20,000 households and about 40,000 individuals and it contains detailed demographic and income information. In particular, it includes questions on both the place of birth and citizenship, the crucial variables that I use to identify migrants. For confidentiality reasons, however, the maximum level of detail on these variables is the grouping into Italian (nationality or place of birth), UE25 and other.

The actual definition of migrants in the data is always problematic and each study takes a somewhat different approach. For example, in the old ECHP, information on the place of birth was missing for too many observations in the Italian sample to allow meaningful analysis (Boeri and Bruecker, 2005; Brucker et al., 2002). Here, I take the same approach as in De Giorgi and Pellizzari (2009) and I define migrants as those individuals who are either born abroad or hold a non-Italian citizenship. This is the definition that yields a total percentage of immigrants in the population that compares best with official data (computed from population registers), which indicate an incidence of about $6.5 \%$ of foreigners in Italy in 2008. The EU-SILC sample is taken from the official population registers and, therefore, it is unlikely to cover illegal migrants.

Table 1 reports some descriptive statistics for the EU-SILC sample that I use in this paper. After dropping some observations due to missing values, I eventually work with approximately 32,000 individual observations. The incidence of foreigners in these data is approximately $6.5 \%$, with a large majority $(5.17 \%$ ) coming from the EU25 and $1.43 \%$ from other sending countries.

The EU-SILC allows the identification of several types of benefit, both at the individual and at the household level. Benefits that are paid to the single individuals are unemployment, sickness and disability and education-related allowances. Family/children benefits, social exclusion provisions and housing allowances are typically paid to the household and I associate to each household member the amount of such benefits divided by the equivalized household size. ${ }^{8}$ Overall, benefit recipiency is higher among migrants than natives: $43.3 \%$ of Italians do receives some kind on non-pension benefit compared to $45.3 \%$ and $50 \%$ of migrants from the EU25 and from other areas.

Following Boeri (2010), these benefits can also be classified into contributory and non-contributory, depending on whether they are financed (primarily) by individual contributions according to an insurance scheme (such as unemployment or sickness insurance) or through general taxation (such as social exclusion provisions). Specifically, I classify unemployment and sickness benefits as contributory and all the others as non-contributory and I find that recipiency is dominated by the latter category of benefits, in particular by family-related allowances.

The mean benefit amount, computed only on those who do receive some, is slightly higher for natives than for migrants who, however, appear to receive more non-contributory than contributory transfers. Overall, transfers account to approximately $10 \%$ of total disposable income (pre-transfers) for the average Italian and to $11 \%$ to $12 \%$ for migrants.

Migrants are generally slightly more educated than natives, although such statistics does not take the quality of education into account. They are also younger, especially those coming from outside the EU and have larger families. Interestingly, there is a higher incidence of females among migrants than natives, especially among those coming from the EU. The data also indicate a high concentration of female immigrant in the sector of personal services (housekeeping, personal care, et.): $18 \%$ of employed female immigrants work in this sector compared to $9.6 \%$ of Italian working women (the

\footnotetext{
${ }^{8}$ I use the standard equivalence scale provided in the EU-SILC which gives weight 1 to the first family member, weight 0.5 to any additional member aged 14 or above and weight 0.3 to any additional member aged 13 or below.
} 
difference for males is a lot smaller and of opposite sign: $5 \%$ vs. $6.2 \%$ ). These results conform with the anecdotical evidence that female immigrants are concentrated in jobs related to the caring of children and old people, an issue that certainly deserves more research as, in some sense, these workers represent a new form or welfare and can be hardly thought of exploiting existing programs.

The second data source that I use in this paper comes from the administrative archives of the National Social Security Administration, INPS (Istituto Nazionale per la Previdenza Sociale). As already outlined in the introduction, anyone applying to a means tested program, including those offered by local administrations, needs to submit an official document that certifies the situation of the households in terms of income and wealth. Such a certificate, called ISEE (Indicatore della Situazione Economica Equivalente) is issued by INPS. The data I use are constructed by sampling individuals enrolled with INPS (which simply requires having paid social security contributions of any kind at some point between 1987 and 2004) and linking such a sample with the archive of the ISEE certificates. ${ }^{9}$. Hence, for those individuals who do not appear in the ISEE archive, i.e. those who never applied for a means tested program, I only know a few basic demographic characteristics, like age, gender and, importantly, the country of birth. For those individuals who do have a ISEE record I also have access to all the characteristics that are included in the ISEE application, e.g. family composition, employment status, income.

Thus, I use the information of whether an individual appears in the ISEE archive as an indicator that he/she applied to some kind of means tested program and I compare such an indicator between Italians and non-Italians. Moreover, within those who do appear in the ISEE archive, I also know how many programs they apply to and a broad categorization of such programs into the areas of family, education, health and other. I concentrate on means test applications submitted in 2005, the most recent year available in the of the INPS-ISEE data, although I also have information on ISEE certificates issued since $2001 .^{10}$ Since the ISEE measures the economic situation of the household, it does not matter who specifically submits the application, the archive contains information on all household members.

The obvious advantage of using the INPS-ISEE data is the possibility to analyze the use of all those locally-administered programmes that are so important in the Italian context. Additionally, these data also contain the fully disaggregated indicator of the country of birth as well as the exact province of residence, a piece of information that will prove extremely important in my analysis in Section 4. The main drawback is the fact that the presence of a ISEE record simply indicates that the person (or someone in his/her household) applied to one or more of such programs but it does not necessarily mean that the application was accepted. It should also be emphasized that, for the obvious reason that only regularly employed workers pay social contributions, the INPS-ISEE data does not cover illegal migrants.

Table 2 reports some descriptive statistics from the INPS-ISEE data. Overall I have 407,154 observations with a distribution across migration status that differs somewhat from what is derived from the EU-SILC. The total percentage of immigrants is estimated at around 10\%, with over 5\% coming from non European countries and the remaining being divided into a $1.3 \%$ from the pre-

\footnotetext{
${ }^{9}$ The sampling is performed on the basis of days of birth. I select all persons of any age born on 4 dates in the calendar year (March 10th, June 10th, September 10th and December 10th). Given the quasi-randomness of births over the calendar year (notice that, having picked a date in each season should make the sampling robust to seasonality in births) such a procedure leads to a random sample of about 1/90 of the reference population (of people enrolled with INPS).

${ }^{10}$ ISEE certificates are valid only for one fiscal year, so if one applies for welfare repeatedly over time, he/she will appear in the ISEE archive with one record for each year in which an application has been submitted.
} 
enlargement EU15 and a 3.2\% arriving from other EU countries. The differences between the EUSILC and the INPS-ISEE data probably come from the sample structure. In particular, the INPS archive does not cover those individuals who have never worked or paid contributions, thus including children and housewives, for example. It also does not cover workers in the public sector, whose social security is administered by a different institution (INPDAP).

In terms of benefit applications, approximately $8 \%$ of individuals in the sample have a ISEE certificate issued in 2005. Such a percentage shows a very interesting variation between Italians and foreigners. Around $7.9 \%$ of natives apply for local welfare as compared to $5.6 \%$ of migrants from the pre-enlargement EU15 and 8.4\% of migrants from other EU countries. The incidence of welfare applications increases to $9.4 \%$ among migrants from other non-European countries. Programs related to education appear to be the most important ones for all types of individuals.

Apart migrants from outside Europe, Table 2 confirms the fact that migrants from Europe are significantly younger than natives. They also appear to be concentrated in the regions of the center and the north. The remaining characteristics - household size, family type and the indicator of economic situation - are only available for individuals who do have a ISEE record. These are, in fact, pieces of information that needs to be included in the application for the means test certificate. In this very selected group, there appears to be a higher incidence of single and working parents among all types of migrants than among Italians. Also, the indicator of the economic situation of the family, which is computed as total household income plus the annual flow value of wealth divided by the equivalized household size, shows a clear ranking that puts Italians first, then people from the EU15, who are likely to be highly skilled migrants, then migrants from other European countries and finally the poorest group is people of non European origins.

\section{Results}

This section presents the results of the analysis of welfare use by migrants in Italy using the two data sources described in Section 3. First, I will discuss results obtained from the EU-SILC data (Section 4.1), then I will turn to the investigation of the INPS-ISEE archive (Section 4.2).

\subsection{Welfare use by migrants in the EU-SILC 2007}

The first set of results that I report in this section is a standard analysis of benefit recipiency as selfreported by respondents in the EU-SILC 2007. Table 3 shows the estimates of a series of probit regressions where the dependent variable is equal to one if the respondent receives any of the nonpension benefits that I consider, either at the individual or at the family level (unemployment, sickness and disability, education-related allowances, family/children benefits, social exclusion provisions and housing allowances).

The set of explanatory variables in the first column only includes the indicators of the country of origin. In particular, I distinguish between migrants from the EU25, from other European countries and from the rest of the world. ${ }^{11}$ Natives are the reference category. The estimates show no significant difference between natives and migrants from the EU25, while migrants from other sending countries do appear to be more likely to receive welfare by approximately 6.5 percentage points, over an average of $43.3 \%$ for natives.

\footnotetext{
${ }^{11}$ This is, in fact, the only classification available from the survey.
} 
The following columns 2 to 5 show how these differences change as the set of control variables is enriched. In column 2 I add standard demographic controls: years of schooling, a quadratic function of age, gender, household size, single parenthood and the number of children below 14 years of age in the family. The estimated coefficient for EU25 migrants now turns even negative and remains highly non-significant while the effect for other migrants is reduced by about $30 \%$ and it is now equal to 4.6 percentage points. Hence, differences in the personal and household characteristics of migrants from outside the European Union do play an important role in explaining differences in welfare use, thus suggesting that selection is indeed a key element. However, the largest part of the difference in welfare use is still unexplained.

In column 3 I, thus, add controls for the labour market status of the individual, namely two indicators for working part-time or full-time with non-employment being the reference category. The estimated effects on migrants' welfare use are hardly affected. This is probably because, on the one hand migrants have higher employment rates than natives, which should lead to lower welfare dependency, but at the same time they earn less on the labour market, thus increasing their relative probability of being in need of financial help.

Next, in column 4 dummies for the region of current residence are added and the estimated residual welfare dependency of migrants from non-EU countries increases to 5.3 percentage points. Unfortunately, the indicator of geographic residence in the EU-SILC is only available at a relatively high level of aggregation, i.e. 5 macro-regions (noth-east, north-west, center, south-east and south-west). I will be able to control for the place of residence in much better details in Section 4.2.

In fact, the role of geographic residence is crucial in the Italian setting. Local welfare is more generous in the richest areas of the country, where local authorities can rely on more abundant financial resources. At the same time, such areas are also those where migrants are more likely to locate for the obvious reason that, typically, the relative demand for unskilled labour is higher. In rich areas Italians are relatively more educated, thus reducing the supply of native unskilled labour and, potentially, increasing the demand for personal services, like housekeeping and child/old-age care (Mazzolari and Ragusa, 2007). Hence, migrants cluster in rich areas and in unskilled occupations, where they earn lower wages than natives, who are concentrated in high-skill jobs. As a consequence, within geographical locations migrants' welfare dependency is relatively high, which explains why the estimated effects increase when conditioning on the macro region of residence.

To support this interpretation, Figure 1 plots the incidence of migrants in the population against value added per inhabitant by province and clearly shows that migrants do indeed cluster in the richest areas of the country. ${ }^{12}$ Next, Figure 2 replicates a similar graph with social expenditure per inhabitant on the vertical axis and confirms the idea that the richest areas are also the ones that offer the most generous welfare. ${ }^{13}$

In Figure 3 I look at the distribution of migrants across occupations and by macro-regions of the country. The figure shows the ratio between migrants and natives across the 9 standard occupational groups, with the most skilled and intellectual ones on the left and most unskilled/manual on the right. ${ }^{14}$ The figure shows some interesting marked differences across regions, which are particularly

\footnotetext{
${ }^{12}$ Value added per inhabitant is the only consistent measure of income at the provincial level. It is computed from the local public accounts.

${ }^{13}$ Unfortunately, official data on social expenditure are only available at the regional level, hence, contrary to Figure 1, Figure 2 can only be produced at such a level of disaggregation.

${ }^{14}$ The precise definitions of the 9 groups is: 1 . Legislators, senior officials and managers; 2 . Professionals; 3 . Technicians and associate professionals; 4. Clerks; 5. Service workers and shop and market sales workers; 6. Skilled agricultural and fishery workers; 7. Craft and related trades workers; 8. Plant and machine operators and assemblers; 9. Elementary
} 
sharp if one compares the North-West and the South, i.e. the richest and the poorest areas of the country. Namely, in the North-West migrants are over represented in the most manual occupations relative to natives and there is a clear trend towards a higher incidence of non-Italian workers in less and less skilled occupations. In the South such a distribution is completely different and migrants seem to be spread across occupations more evenly. In other words, while in the South migrants and natives compete for the same jobs, the natives of the North are more skilled on average and therefore do not suffer from the competition with the low-skilled migrants, who are concentrated in different jobs.

Consistently with this last finding, Figure 4 reports the ratios between the average income of migrants and that of natives across the same 5 macro-regions of Figure 3. The figure shows a very clear trend towards higher relative incomes in the South than in the North, particularly in the NorthWest. In this last area, the average income of migrants is around $83 \%$ that on natives and it increases moving towards the South of the country, reaching $89 \%$ in the South. Despite these differences in relative incomes, it remains true that the average income of migrants located in the North of the country is higher that that of migrants in the South.

Hence, the important role of geographical location in the estimates of Table 3 is the result of very limited differences in welfare use between migrants and natives in the South of the country where welfare is not particularly generous anyway - and larger differences in the North, where most migrants are located. In section 4.2 I will be able to control for a much more detailed indicator of geographical residence (the province) and, consistently with the above argument, the increase in the estimated welfare dependency will be even more pronounced.

One additional effects that is captured by the regional dummies is the presence of migrants' networks, which have been documented to play a very important role in the determination of many social and economic outcomes (Bauer et al., 2009; Carrington et al., 2001; Thomas Bauer, 2007; Winters et al., 2001). Such an effect reinforces the concentration of migrants in high-wage areas as they would first settle there because of the favourable economic conditions and then, as soon as a critical mass of migrants from one same country (or area) of origin is reached, also because they can rely on the support of the network. And migrants' networks may also offer information about available welfare programs as well as assistance with the applications.

Finally, in the last column, column 5, I include the equivalized income. ${ }^{15}$ This last control is eventually capable of eliminating any statistically significant difference between native and migrants of any origin. The coefficient on migrants from outside Europe drops to 0.015 and becomes insignificant. Notice that the standard error does not change much compared to the previous columns, so that one can be reassured that the loosing of statistical significance does not come from higher collinearity in the model due to the increased dimensionality of the control set.

This result suggests that differences in the use of welfare between natives and migrants for given observable characteristics are due the fact that, other things being equal, migrants earn less on the market (or have fewer incomes from other sources). The literature that explores the reasons for such differences is huge and has proposed a variety of arguments, from pure discrimination to differences in culture and values to differences in access to job search networks (Borjas, 1995, 1999b; Bratsberg, Barth, and Raaum, 2006; Dustmann, Glitz, and Vogel, 2010).

Tables 4 and 5 replicate the same exercise of Table 3, focusing on contributory and non-contributory

occupations.

${ }^{15}$ Equivalized income is used in levels rather than logs, as it is perhaps more customary, because I do not want to drop those with zero income, a group that is likely to use welfare intensively. 
programs, respectively. Results show that the inclusion of additional observable controls is able explain any additional welfare dependency by migrants for non-contributory benefits but not for contributory ones. ${ }^{16}$ Separate regressions for unemployment and sickness benefits alone show that residual dependency in the case of contributory benefits is due to a higher incidence of recipients of sickness benefits among migrants.

A possible interpretation of such a results is that migrants are subject to a higher risk of work accidents, either because they are concentrated in risker occupations (e.g. construction and manufacturing) or because they are more willing to be assigned to riskier tasks, perhaps due to lower outside options.

It is also worth noticing that conditioning on the geographical dummies has a stronger effect on the coefficients estimated for non-contributory benefits (Table 5) than for contributory ones (Table 4). This is consistent with my interpretation, given than all the contributory programs are centrally administered and therefore eligibility doe not depend (at least directly) to one's location.

\subsection{Welfare use by migrants in the INPS-ISEE archive}

As I discussed already at length in the introduction and in section 2, the EU-SILC is unlikely to capture the use of the myriad of welfare programs that are offered at the very local level and that play such an important role in the Italian system. These programs are often in kind rather than monetary transfers, or sometimes a combination of both. For example, some municipalities deliver hot meals at home to old people or provide social housing, others have housing benefits or give preferred or discounted places in public old age residences or child care institutes.

The INPS-ISEE data allow to investigate differences in the rate of application to all those local welfare programs between migrants and natives. Table 6 reports the results of a series of probit regressions where the dependent variable is equal to 1 for those individuals who appear to have a ISEE record in 2005, these are individuals who have submitted an application to obtain a ISEE certificate to be included in the application for some kind of means tested welfare program.

Similarly to Tables 3,4 and 5, the model in the first column of Table 6 only includes a set of dummies for the country of origin, with natives being the reference group. In the following columns the set of controls is enlarged to include first demographic characteristics (column 2) and then (column 3) also dummies for the region of residence (20 dummies). Finally, in column 4 I explore the relative elasticity of the application rates of migrants and natives to the level of local unemployment. This exercise is only possible with the INPS-ISEE data, where one has information on the province of residence, hence in the regression in Table 6 I still include the regional dummies and I use the level of unemployment in the province as an indicator of the labour market conditions. There are over 100 provinces in Italy, a number that is sufficiently large to guarantee the identification of the effect of the unemployment rate within the region.

Unfortunately, the set of possible controls is limited by the fact that I can only use the few pieces of information that can be derived from the demographic archive at INPS. In fact, although the ISEE archive does contain additional variables, those are not available for the individuals who did not submit an ISEE application, which are all the zeros in the dependent variable of the models estimated in Table 6. Later on, in Table 8 I run a different specification that allows me to use all the variables that can be derived from the ISEE archive.

\footnotetext{
${ }^{16}$ Note that this results contrasts with the finding in Boeri (2010), the difference being that I do not consider old age and survivors benefits in my analysis.
} 
One important advantage of the INPS-ISEE data is the possibility to reconstruct the actual country of birth so that in Table 6 (and also in all the following ones) I can distinguish between migrants from the old EU15, for whom it is plausible to assume a strong positive selection on skills, migrants from other European countries and migrants from other continents.

Results in the first column of Table 6 show that, while migrants from the pre-enlargement EU15 are significantly less likely than natives to apply for local welfare $(-2.3 \%)$, the effect is of the opposite sign for those arriving from outside Europe $(+1.5 \%)$. These differences are also quantitatively important as compared to the average application rate of around $8 \%$ for natives. On the other hand, migrants from other European countries are only marginally more likely than native to use local welfare by a mere $0.4 \%$.

Including same simple demographic controls changes things substantially, especially for nonEuropean migrants, whose coefficients is reduced to $+0.4 \%$. The estimated difference between natives and EU15 migrants changes only slightly and decreases to a $-2.6 \%$, while the small effect previously estimated for other European migrants now disappears. Once again, this result confirms that the process of migrants' self-selection is paramount to understand why their unconditional welfare dependency is higher than that of natives (De Giorgi and Pellizzari, 2009).

The results in column 3 of Table 6 , further show that also the selection of migrants into different geographical areas within Italy is extremely important. In fact, the control set in column 3 is augmented with indicators for the region of residence and, for the same reasons discussed in Section4.1, the estimates for both non-EU15 European migrants and migrants from other continents increase substantially to $\mathrm{s}+2.3 \%$ and $+2.7 \%$, respectively. Notice that, compared to the results in Table 3 (but also Table 4 and Table 5) where the inclusion of macro-region dummies led to an increase in the coefficient that measures residual welfare dependency by approximately $17 \%$ (14\% in Table 4 and $23 \%$ in Table 5), being able to control for geographical location at a much more detailed level with regional dummies, as in Table 6, now generate an increase in the same coefficient in order of almost 7 times. The results for EU15 migrants are only marginally affected by the introduction of regional dummies, suggesting that this group does not choose their final destination on the basis of the generosity of local welfare and that their labour market performance is more comparable to that of natives.

These results emphasise the importance of the analysis of data, like the INPS-ISEE archive, that allow to take into consideration the high degree of heterogeneity of welfare provision at the local level. In unreported regressions, I also experimented with province dummies and results are very similar to those reported in Table 6, suggesting that most of such heterogeneity is distributed across regions rather than across provinces (or cities) within regions.

In the last column of Table 6 I exploit the geographical detail of the data to produce estimates of the elasticity of welfare applications to changes in the conditions of the local labour market, an issue of particular interest given the severity of the current economic crisis. This is an exercise that, to my knowledge, has never been carried out before, I suspect because of data limitations. In fact, when one wants to estimate the effect of a macro variable, like the unemployment rate, in an empirical model where the unit of observation is the single individual, one has to confront the problem that such macro variable may also capture the effect of other local conditions. Put it simply, one would like to estimate the effect of the local unemployment rate while, at the same time, controlling for local fixed effects. But, if the unemployment rate is computed at the same level of disaggregation of the local fixed effects the model is not identified (the unemployment rate and the local fixed effects are perfectly collinear). So, for example, in the EU-SILC one could not include in a regression the 
unemployment rate in the macro region together with the macro region fixed effect.

In the INPS-ISEE data the place of residence is identified at the level of the province, hence it is possible to augment the control set of the regressions in Table 6 with the unemployment rate in the province while still conditioning on regional dummies. In this specification, the identification of the coefficient on the unemployment rate rests on the assumption that all other local effects are constant at the regional level.

Column 4 in Table 6 reports the estimates of the same model of column 3 with the local unemployment rate interacted with the indicators for migrants. Overall, an increase in local unemployment by 1 percentage point, over an average of $7.9 \%$, corresponding to approximately $20 \%$ of a standard deviation, increases the application rate of natives by 0.2 percentage points or $2.5 \%$ of the average. The following interactions coefficients allow to explore how such an effect vary across types of migrants. For people coming from the EU15, the effect is only slightly (but statistically significantly) stronger by a 0.1 of a percentage point.

Interestingly, the estimates for both migrants from other European countries and from other continents are negative and large enough to reverse the main effect. Both groups appear to reduce their application rate in the face of increasing unemployment. This is a result that certainly requires more research but, as a first approximation, one could think of at least two mechanisms that may generate it. First, since migrants, almost by definition, have a higher propensity than natives to move in search of good economic conditions, a rise in unemployment may lead them to leave the area rather than to apply for welfare. Second, since migrants do appear to be paid less in labour market (due either to discrimination or to lower effective skills or to lower bargaining power), employers may substitute native with foreign workers in times of economic hardship. Generally speaking, this result also suggests that worries about a more acute exploitation of welfare services by migrants during recessions seem to be misplaced.

One additional piece of information that can be extracted from the the ISEE archive is the type of welfare program the means test certificate is used for. Four possible areas can be indicated: family, education, health and a residual group (other). Table 7 reports the estimates of models similar to the one in column 3 of Table 6 where the dependent variable is replaced with a dichotomous indicator for ISEE submissions in each of the above mentioned areas.

Results show some interesting variation across program types and migrant groups. Family programs, which account for about $20 \%$ of all applications, are, ceteris paribus, requested more often by migrants from outside Europe and less by the other groups. The effects are relatively small but should be compared with an application rate of around 1.5\% among natives. Interestingly, education related programs are still requested less frequently by EU15 migrants but more often by individuals coming from other European countries and by migrants from other continents. There does not seem to be any significant difference in applications for health-related programs across all groups. Finally, results for the residual category resemble very much what is reported in Table 7 .

The analysis of Tables 6 and 7 suggests the presence of a higher degree of residual welfare dependency that what one could infer from the EU-SILC data only. However, the limited set of control variables leaves the suspicion that such results might be driven by things like family composition or income, that cannot be observed for all individuals in the INPS-ISEE data. For this reason, in Table 8 I concentrate exclusively on observations that do have a corresponding ISEE record, which includes numerous additional variables, and I define the dependent variable as the number of applications submitted in 2005. In fact, one piece of information that applicants must include in their ISEE request is the number of programs they are applying to. This is needed because the Social Security Adminis- 
tration (INPS) sends the means tests certificates directly to the local administrations that implement the programs.

The drawback of this approach is, obviously, the loss of those individuals who do not apply to any program. The advantage, thou, is the possibility to enrich the control set a lot more than what could be done in the exercises reported in Tables 6 and 7. Given that the dependent variable is a count variable, the model is estimated using a poisson regression.

The unconditional differences in the number of welfare applications reported in column 1 of Table 8 indicate that, conditional on submitting at least one application, Italians apply to more programs than any type of migrant but those from the pre-enlargement EU15, for whom no difference can be detected. These effects remain statistically significant and rather constant also in columns 2 and 3, where individual and household characteristics are introduced. In column 4 I also add regional dummies and the effect disappears for migrants from other European countries but remains significant for those coming from outside Europe. For this last group, however, the coefficient is reduced by approximately two thirds. Such a result confirms the importance of the process of endogenous location decisions that migrants make within Italy. Finally, in column 5 I further expand the control set with the actual value of the means test, i.e. a measure of equivalized income and wealth of the household. Results are hardly affected.

\section{Conclusions}

In this paper I presented an analysis of migrants welfare dependency in Italy that differs from all previous studies in its use of a combination of survey and administrative data. While the survey data, taken from the most recent (2007) EU-SILC, allow me to replicate existing findings and compare results with other papers, they are unlikely to capture the use of the myriad of welfare programs offered at the very local level.

The geographical heterogeneity of the Italian welfare system is a well know peculiarity but one that has never been properly acknowledged in studies of welfare use. The comparison of results based on the EU-SILC and on my administrative data, indeed, suggests that many important features of migrants' welfare dependency could not be detected exclusively with survey data.

In particular, I find that geographical location is paramount. Migrants naturally concentrate in rich areas where the relative supply of skilled workers is high and there is demand for unskilled labour. Hence, they work in jobs that are comparatively less well paid that those hold by natives. As a consequence, they earn less and, having also larger families, they tend to use the local welfare system more intensively than observationally similar Italians.

From the policy perspective, the results presented in this paper confirm the idea that the selection of migrants is important and, therefore, if the government wants to reduce welfare dependency it should, perhaps, implement migration policies that favour the arrival of skilled persons. At the same time, however, I also show that the selection of locations within the country is equally, if not more important. Specifically, the heterogeneity of welfare provisions across Italy may have the potential to increase dependency and worsen the citizens' view of immigration. Policy aimed at harmonizing the provision of local welfare programs may prove beneficial in this respect.

The findings in this paper also bear a more general message, despite being produced with very specific Italian data, and speak to all those contexts where welfare is heterogeneous across geographical areas, like Germany or the United States. 


\section{References}

Massimo Baldini, Paolo Bosi, and Stefano Toso. Targeting welfare in Italy: Old problems and perspectives of reforms. CAPP Materiali di Discussione n. 337, 2000.

Alan Barrett and Yvonne McCarthy. Immigrants in a booming economy: Analysing their earnings and welfare dependence. Labour, 21(5-5):789-808, 2007.

Alan Barrett and Yvonne McCarthy. Immigrants and welfare programmes: exploring the interactions between immigrant characteristics, immigrant welfare dependence, and welfare policy. Oxford Review of Economic Policy, 24(3):542-559, 2008.

Thomas Bauer, Gli S. Epstein, and Ira N. Gang. Measuring ethnic linkages among migrants. International Journal of Manpower, 30(1+2):56-69, 2009.

Tito Boeri. Immigration to the land of redistribution. Economica, 2010. forthcoming.

Tito Boeri and Herbert Bruecker. Why are Europeans so tough on migrants? Economic Policy, 44: 629-704, 2005.

Tito Boeri, Orietta Dessy, Pietro Garibaldi, Paola Monti, and Michele Pellizzari. Per un atterraggio morbido. In Richard Baldwin, Giorgio Barba Navaretti, and Tito Boeri, editors, Come sta cambiando l'Italia. Il Mulino, 2007.

George J. Borjas. Assimilation and changes in cohort quality revisited: What happened to immigrant earnings in the 1980s? Journal of Labor Economics, 13(2):201-245, 1995.

George J. Borjas. Immigrant and welfare magnets. Journal of Labor Economics, 17(4):607-637, 1999a.

George J. Borjas and Lynette Hilton. Immigration and the welfare state: Immigrant participation in means-tested entitlement programs. Quarterly Journal of Economics, 111(2):575-604, 1996.

George J. Borjas and Stephen J. Trejo. Immigrant participation in the welfare system. Industrial and Labor Relations Review, 44(2):195-211, 1991.

Geroge J. Borjas. The economic analysis of immigration. In David Card Orley Ashenfelter, editor, Handbook of Labor Economics, pages 1697-1760. Elsevier, 1999b.

Bernt Bratsberg, Erling Barth, and Oddbjørn Raaum. Local unemployment and the relative wages of immigrants: Evidence form the Current Population Surveys. Review of Economics and Statistics, 88(2):243-263, 2006.

Bernt Bratsberg, Oddbjørn Raaum, and Knut Roed. When minority labor migrants meet the welfare state. Journal of Labor Economics, 2007. forthcoming.

Herbert Brucker, Gil Epstein, Gilles Saint-Paul, Alessandra Venturini, and Klaus Zimmerman. Welfare state provision. In Tito Boeri, Gordon Hanson, and Barry McCormick, editors, Immigration Policy and the Welfare State, pages 66-90. Oxford: Oxford University Press, 2002. 
William J. Carrington, Enrica Detragiache, and Tara Vishwanath. Migration with endogenous moving costs. American Economic Review, 86(4):909-930, 2001.

Edward J. Castronova, Hilke Kayser, Joachim R. Frick, and Gert G. Wagner. Immigrants, natives and social assistance: Comparable take-up under comparable circumstances. International Migration Review, 35(1):726-748, 2001.

Giacomo De Giorgi and Michele Pellizzari. Welfare magnets in Europe. Labour Economics, 16(4): 353-363, 2009.

Christian Dustmann. Return migration,uncertainty and precautionary savings. Journal of Development Economics, 52:295-316, 1997.

Christian Dustmann, Tommaso Frattini, and Caroline Halls. Assessing the fiscal costs and benefits of A8 migration to the UK. CReAM Discussion Paper Series 0918, 2009.

Christian Dustmann, Albrecht Glitz, and Thorsten Vogel. Employment, wages, and the economic cycle: Differences between immigrants and natives. European Economic Review, 2010. forthcoming.

Maria E. Enchautegui. Welfare payments and other economic determinants of female migration. Journal of Labor Economics, 15(3):529-554, 1997.

Jonah B. Gelbach. Migration, the life cycle, and state benefits: How low is the bottom? Journal of Political Economy, 112(5):1091-1130, 2004.

Edward M. Gramlich and Deborah S. Laren. Migration and income redistribution responsibilities. Journal of Human Resources, 19(4):489-511, 1984.

Jörgen Hansen and Magnus Lofstrom. Immigrant assimilation and welfare participation: Do immigrants assimilate into or out of welfare? Journal of Human Resources, 38(1):74-98, 2003.

Virginia Hernanz, Franck Malherbet, and Michele Pellizzari. Take-up of welfare benefits. OECD Social, Employment and Migration Working Papers n. 17, 2000.

Phillip B. Levine and David J. Zimmerman. An empirical analysis of the welfare magnet debate using the NLSY. Journal of Population Economics, 12(3):391-409, 1999.

Francesca Mazzolari and Giuseppe Ragusa. Spillovers from high-skill consumption to low-skill labor markets. IZA Discussion Papers N. 3048, 2007.

Terra McKinnish. Importing the poor: Welfare magnetism and cross-border migration. Journal of Human Resources, 40(1):57-76, 2005.

Terra McKinnish. Welfare-induced migration at state borders: New evidence from microdata. Journal of Public Economics, 91(3-4):437-450, 2007.

Bruce D. Meyer. Do the poor move to receive higher welfare benefits? Northwestern University, Joint Center for Poverty Research Working Paper N. 58, 2000. 
Paola Monti and Michele Pellizzari. Implementing a guaranteed minimum income in italy: An empirical analysis of costs and political feasibility. Giornale degli Economisti e Annali di Economia, 2010. forthcoming.

Regina T. Riphahn. Immigration participation in social assistance programs. Applied Economics Quarterly, 50(4), 2004.

Robert Rowthorn. The fiscal impact of immigration on the advanced economies. Oxford Review of Economic Policy, 24(3):560-580, 2008.

Kjetil Storesletten. Sustaining fiscal policy through immigration. Journal of Political Economy, 108(2):300-323, 2000.

Ira N. Gang Thomas Bauer, Gli S. Epstein. Herd effects or migration networks? The location choice of mexican immigrants in the U.S. Research in Labor Economics, 26:199-229, 2007.

Paul Winters, Alain de Janvry, and Elisabeth Sadoulet. Family and community networks in MexicoUS migration. Journal of Human Resources, 36(1):159-184, 2001. 


\section{Figures}

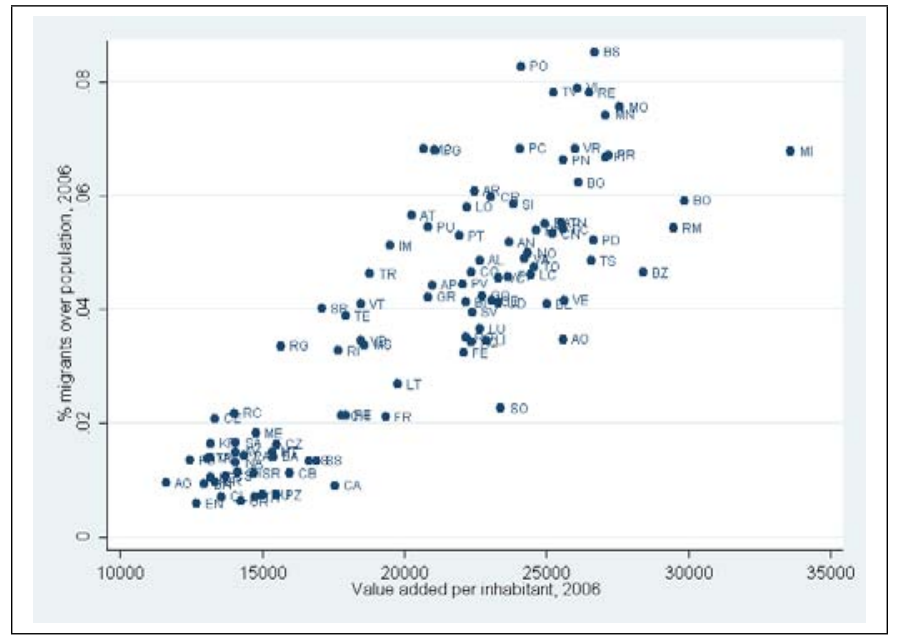

Figure 1: Migrants and value added by province

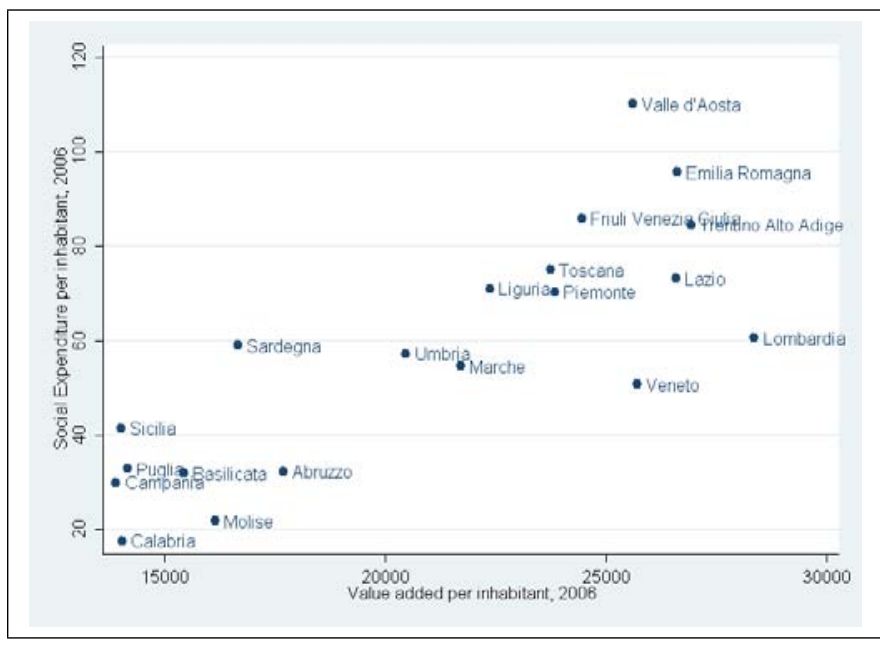

Figure 2: Social expenditure and value added by region 


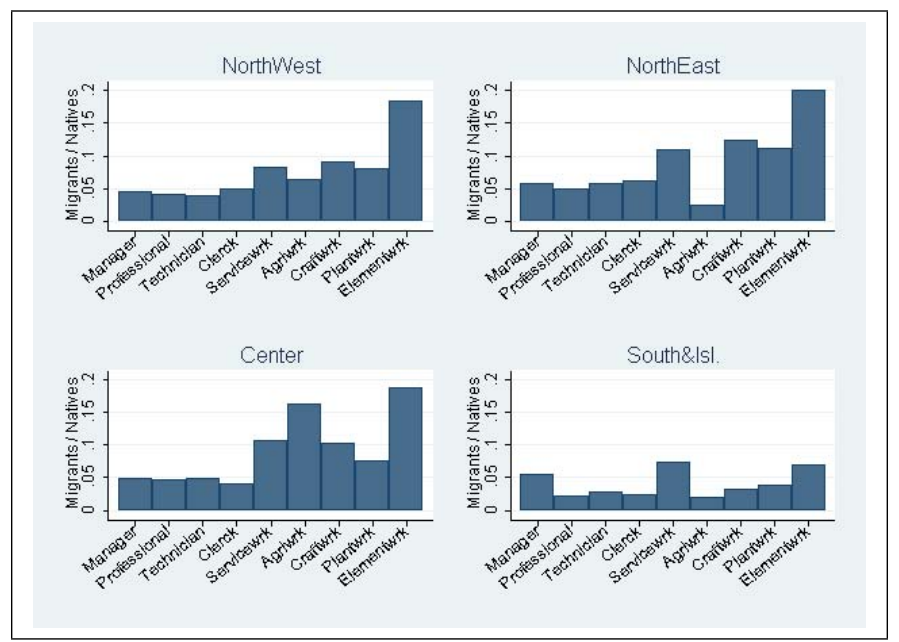

Figure 3: Distribution of migrants by occupation and region

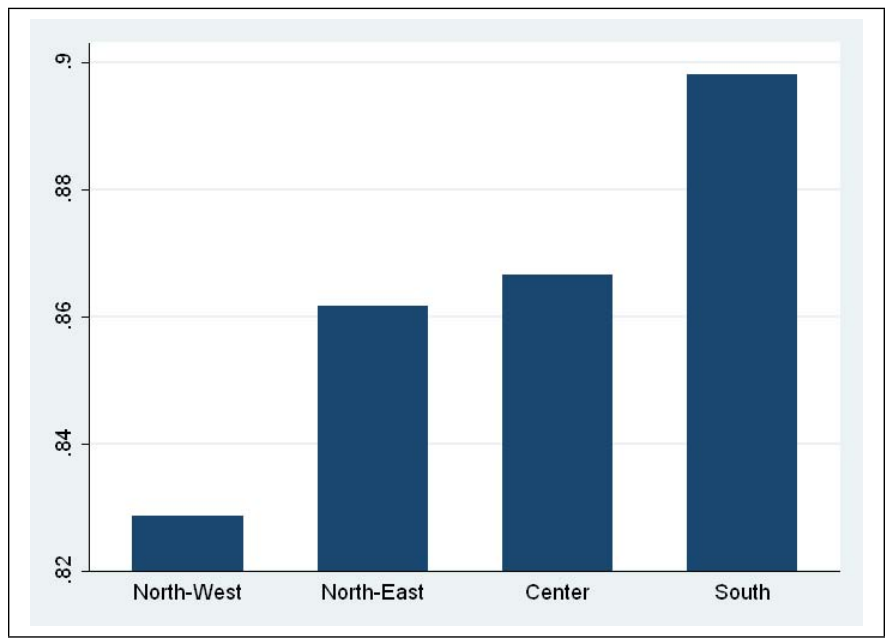

Figure 4: Relative incomes of migrants by region 
Tables 
Table 1: Descriptive statistics of the Italian EU-SILC sample

\begin{tabular}{|c|c|c|c|}
\hline & \multirow[t]{2}{*}{ Citizen } & \multicolumn{2}{|c|}{ Migrants } \\
\hline & & EU25 & Other \\
\hline Sample size & 30,169 & 1,607 & 465 \\
\hline$\%$ pop & 93.46 & 5.17 & 1.43 \\
\hline Welfare use: & & & \\
\hline$\%$ Receiving benefit & 43.34 & 45.31 & 49.84 \\
\hline$\%$ Receiving contributory & 15.47 & 14.96 & 19.98 \\
\hline$\%$ Receiving non-contributory & 34.31 & 36.38 & 39.02 \\
\hline Total transfers & $\begin{array}{c}1,800.45 \\
(3,455.83)\end{array}$ & $\begin{array}{c}1,739.74 \\
(2,678.48)\end{array}$ & $\begin{array}{c}1,412.89 \\
(1,758.97)\end{array}$ \\
\hline Contributory benefits & $\begin{array}{c}694.90 \\
(2,555.40)\end{array}$ & $\begin{array}{c}497.63 \\
(1,547.91)\end{array}$ & $\begin{array}{c}524.81 \\
(1,490.96)\end{array}$ \\
\hline Non-contributory benefits & $\begin{array}{c}638.60 \\
(1,312.89)\end{array}$ & $\begin{array}{c}892.661 \\
(1,329.39)\end{array}$ & $\begin{array}{c}811.66 \\
(1,077.41)\end{array}$ \\
\hline Individual characteristics: & & & \\
\hline $\begin{array}{l}\text { Equivalized pre-transfers } \\
\text { income }\end{array}$ & $\begin{array}{c}15,757.95 \\
(12,685.44)\end{array}$ & $\begin{array}{c}14,409.33 \\
(10,309.74)\end{array}$ & $\begin{array}{c}12,680.5 \\
(9,457.07)\end{array}$ \\
\hline Years of schooling & $\begin{array}{l}12.90 \\
(7.26)\end{array}$ & $\begin{array}{l}13.95 \\
(7.14)\end{array}$ & $\begin{array}{l}13.48 \\
(7.21)\end{array}$ \\
\hline Age & $\begin{array}{c}41.34 \\
(13.11)\end{array}$ & $\begin{array}{c}40.36 \\
(10.95)\end{array}$ & $\begin{array}{c}37.73 \\
(10.85)\end{array}$ \\
\hline$\%$ female & 50.05 & 63.84 & 53.83 \\
\hline$\%$ single parent & 2.55 & 4.68 & 2.61 \\
\hline$\% 0$ child & 47.59 & 43.97 & 39.76 \\
\hline$\% 1$ child & 31.14 & 30.36 & 37.77 \\
\hline$\% 2$ children & 16.81 & 19.42 & 17.24 \\
\hline$\% 3$ or more children & 4.46 & 6.25 & 5.23 \\
\hline Geographical location: & & & \\
\hline$\%$ North west & 21.31 & 15.85 & 24.27 \\
\hline$\%$ North east & 22.74 & 32.81 & 31.49 \\
\hline$\%$ Center & 23.37 & 22.77 & 29.12 \\
\hline$\%$ South & 23.72 & 18.75 & 11.39 \\
\hline \% Islands & 8.85 & 9.82 & 3.73 \\
\hline
\end{tabular}

Means and (std. deviations) 
Table 2: Descriptive statistics of the INPS-ISEE sample

\begin{tabular}{lccccc}
\hline \hline & Citizens & EU15 & $\begin{array}{c}\text { Migrants } \\
\text { Other Europe }\end{array}$ & Extra Europe & Sample Size \\
\hline Individuals & 366,089 & 5,647 & 13,739 & 21,625 & 407,154 \\
\%pop & 89.91 & 1.38 & 3.37 & 5.31 & 407,154 \\
\%Requesting benefit & 7.94 & 5.64 & 8.38 & 9.44 & 407,154 \\
\%Requesting family benefit & 1.53 & 1.48 & 1.67 & 2.13 & 407,154 \\
\%Requesting edu benefit & 4.88 & 3.29 & 4.88 & 4.47 & 407,154 \\
\%Requesting health benefit & 0.59 & 0.44 & 0.29 & 0.31 & 407,154 \\
\%Requesting other benefit & 4.64 & 3.25 & 5.02 & 6.08 & 407,154 \\
\%Female & 47.91 & 55.14 & 47.37 & 34.31 & 407,154 \\
Mean age & 44.88 & 42.10 & 39.95 & 40.89 & 407,154 \\
& $(12.46)$ & $(10.05)$ & $(9.79)$ & $(9.52)$ & \\
\%Resident in north west & 25.96 & 23.80 & 22.56 & 35.25 & 407,154 \\
\%Resident north east & 18.48 & 21.40 & 30.65 & 22.15 & 407,154 \\
\%Resident center & 20.22 & 23.01 & 27.83 & 26.26 & 407,154 \\
\%Resident south east & 10.39 & 11.03 & 8.41 & 04.23 & 407,154 \\
\%Resident south west & 24.92 & 20.75 & 10.53 & 12.10 & 407,154 \\
Mean household size & 3.66 & 3.62 & 3.66 & 3.69 & 32,605 \\
& $(1.27)$ & $(1.19)$ & $(1.41)$ & $(1.58)$ & 32,605 \\
\%Employed & 61.41 & 63.63 & 78.11 & 79.87 & 32,605 \\
\%Single parent & 6.72 & 8.15 & 11.33 & 10.99 & 32,605 \\
\%Work parent & 12.08 & 15.36 & 17.21 & 13.20 & 32,605 \\
Equivalized income & $22,908.41$ & $18,700.05 .92$ & $14,027.82$ & $13,795.61$ & 28,931 \\
and wealth (if $>0)$ & $(20,695.78)$ & $(20,765.78)$ & $(11,454.96)$ & $(11,102.05)$ & \\
\hline \hline
\end{tabular}

Means and (std. deviations) 
Table 3: Benefit recipiency in the EU-SILC 2007

\begin{tabular}{|c|c|c|c|c|c|}
\hline \multicolumn{6}{|c|}{ Dependent variable $=1$ if receiving any non-pension benefit } \\
\hline & (1) & (2) & (3) & (4) & $(5)$ \\
\hline \multicolumn{6}{|l|}{ Country of origin: } \\
\hline $1=\mathrm{EU} 25$ & $\begin{array}{c}0.009 \\
(0.023)\end{array}$ & $\begin{array}{l}-0.002 \\
(0.024)\end{array}$ & $\begin{array}{l}-0.007 \\
(0.024)\end{array}$ & $\begin{array}{l}-0.007 \\
(0.024)\end{array}$ & $\begin{array}{l}-0.021 \\
(0.024)\end{array}$ \\
\hline $1=$ other countries & $\begin{array}{c}0.065 * * * \\
(0.013)\end{array}$ & $\begin{array}{c}0.046 * * * \\
(0.013)\end{array}$ & $\begin{array}{c}0.045^{* * *} * \\
(0.013)\end{array}$ & $\begin{array}{c}0.053 * * * \\
(0.013)\end{array}$ & $\begin{array}{c}0.015 \\
(0.013)\end{array}$ \\
\hline \multicolumn{6}{|c|}{ Individual and household characteristics: } \\
\hline Years of schooling & & $\begin{array}{c}-0.006^{* * * *} \\
(0.000)\end{array}$ & $\begin{array}{c}-0.005^{* * *} \\
(0.000)\end{array}$ & $\begin{array}{c}-0.005^{* * * *} \\
(0.000)\end{array}$ & $\begin{array}{c}-0.004 * * * \\
(0.000)\end{array}$ \\
\hline Age & & $\begin{array}{c}0.021 * * * \\
(0.001)\end{array}$ & $\begin{array}{c}0.029 * * * \\
(0.002)\end{array}$ & $\begin{array}{c}0.029 * * * \\
(0.002)\end{array}$ & $\begin{array}{c}0.027 * * * \\
(0.002)\end{array}$ \\
\hline Age squared & & $\begin{array}{c}-0.000^{* * *} \\
(0.000)\end{array}$ & $\begin{array}{c}-0.000^{* * *} * \\
(0.000)\end{array}$ & $\begin{array}{c}-0.000^{* * * *} \\
(0.000)\end{array}$ & $\begin{array}{c}-0.000 * * * \\
(0.000)\end{array}$ \\
\hline $1=$ female & & $\begin{array}{l}-0.007 \\
(0.006)\end{array}$ & $\begin{array}{c}-0.034 * * * \\
(0.006)\end{array}$ & $\begin{array}{c}-0.032 * * * \\
(0.006)\end{array}$ & $\begin{array}{c}-0.023 * * * \\
(0.006)\end{array}$ \\
\hline HH size & & $\begin{array}{c}0.093 * * * \\
(0.006)\end{array}$ & $\begin{array}{c}0.089 * * * \\
(0.006)\end{array}$ & $\begin{array}{c}0.081 * * * \\
(0.006)\end{array}$ & $\begin{array}{c}0.079 * * * \\
(0.006)\end{array}$ \\
\hline $1=$ single parent & & $\begin{array}{c}0.099 * * * \\
(0.018)\end{array}$ & $\begin{array}{c}0.099 * * * \\
(0.018)\end{array}$ & $\begin{array}{c}0.098 * * * \\
(0.018)\end{array}$ & $\begin{array}{c}0.065^{* * * *} \\
(0.018)\end{array}$ \\
\hline Num. of kids $(<14)$ & & $\begin{array}{c}0.101 * * * \\
(0.004)\end{array}$ & $\begin{array}{c}0.098 * * * \\
(0.004)\end{array}$ & $\begin{array}{c}0.097 * * * \\
(0.004)\end{array}$ & $\begin{array}{c}0.101 * * * \\
(0.004)\end{array}$ \\
\hline \multicolumn{6}{|l|}{ Labour market status: } \\
\hline $1=$ working full time & & & $\begin{array}{c}-0.089 * * * \\
(0.007)\end{array}$ & $\begin{array}{c}-0.080 * * * \\
(0.007)\end{array}$ & $\begin{array}{c}-0.022 * * * \\
(0.007)\end{array}$ \\
\hline $1=$ working part-time & & & $\begin{array}{l}-0.009 \\
(0.012)\end{array}$ & $\begin{array}{c}0.001 \\
(0.012)\end{array}$ & $\begin{array}{c}0.032 * * * \\
(0.012)\end{array}$ \\
\hline Equivalized income & & & & & $\begin{array}{c}-0.000 * * * \\
(0.000)\end{array}$ \\
\hline Regional dummies & No & No & No & Yes & Yes \\
\hline Observations & 32,251 & 32,251 & 32,251 & 32,251 & 32,251 \\
\hline
\end{tabular}

All models are estimated as probit regressions. The reported estimates are marginal effects computed at the average of all the control variables. 
Table 4: Recipiency of contributory benefits in the EU-SILC (2007)

\begin{tabular}{|c|c|c|c|c|c|}
\hline \multicolumn{6}{|c|}{ Dependent variable $=1$ if receiving any contributory benefit } \\
\hline & $(1)$ & $(2)$ & (3) & (4) & $(5)$ \\
\hline \multicolumn{6}{|l|}{ Country of origin: } \\
\hline \multirow[t]{2}{*}{$1=\mathrm{EU} 25$} & -0.008 & -0.011 & -0.013 & -0.015 & -0.020 \\
\hline & $(0.017)$ & $(0.016)$ & $(0.016)$ & $(0.016)$ & $(0.015)$ \\
\hline \multirow[t]{2}{*}{$1=$ other countries } & $0.045^{* * *}$ & $0.034 * * *$ & $0.034 * * *$ & $0.039 * * *$ & $0.024 * *$ \\
\hline & $(0.010)$ & $(0.010)$ & $(0.010)$ & $(0.010)$ & $(0.010)$ \\
\hline \multicolumn{6}{|c|}{ Individual and household characteristics: } \\
\hline \multicolumn{2}{|l|}{ Years of schooling } & $\begin{array}{c}-0.002 * * * \\
(0.000)\end{array}$ & $\begin{array}{c}-0.002 * * * \\
(0.000)\end{array}$ & $\begin{array}{c}-0.002 * * * \\
(0.000)\end{array}$ & $\begin{array}{c}-0.001 * * * \\
(0.000)\end{array}$ \\
\hline Age & & $\begin{array}{c}0.015 * * * \\
(0.001)\end{array}$ & $\begin{array}{c}0.018 * * * \\
(0.001)\end{array}$ & $\begin{array}{c}0.017 * * * \\
(0.001)\end{array}$ & $\begin{array}{c}0.017 * * * \\
(0.001)\end{array}$ \\
\hline Age squared & & $\begin{array}{c}-0.000 * * * \\
(0.000)\end{array}$ & $\begin{array}{c}-0.000 * * * \\
(0.000)\end{array}$ & $\begin{array}{c}-0.000 * * * \\
(0.000)\end{array}$ & $\begin{array}{c}-0.000 * * * \\
(0.000)\end{array}$ \\
\hline $1=$ female & & $\begin{array}{c}-0.027 * * * \\
(0.004)\end{array}$ & $\begin{array}{c}-0.041 * * * \\
(0.004)\end{array}$ & $\begin{array}{c}-0.040^{* * * *} \\
(0.004)\end{array}$ & $\begin{array}{c}-0.036^{* * *} * \\
(0.004)\end{array}$ \\
\hline HH size & & $\begin{array}{c}0.009^{* * *} \\
(0.004)\end{array}$ & $\begin{array}{l}0.007 * \\
(0.004)\end{array}$ & $\begin{array}{c}0.003 \\
(0.004)\end{array}$ & $\begin{array}{c}0.002 \\
(0.004)\end{array}$ \\
\hline $1=$ single parent & & $\begin{array}{c}0.019 \\
(0.014)\end{array}$ & $\begin{array}{c}0.018 \\
(0.014)\end{array}$ & $\begin{array}{c}0.019 \\
(0.014)\end{array}$ & $\begin{array}{c}0.006 \\
(0.013)\end{array}$ \\
\hline Num. of kids $(<14)$ & & $\begin{array}{c}-0.029 * * * \\
(0.003)\end{array}$ & $\begin{array}{c}-0.030 * * * \\
(0.003)\end{array}$ & $\begin{array}{c}-0.031 * * * \\
(0.003)\end{array}$ & $\begin{array}{c}-0.031 * * * \\
(0.003)\end{array}$ \\
\hline \multicolumn{6}{|l|}{ Labour market status: } \\
\hline $1=$ working full time & & & $\begin{array}{c}-0.034 * * * \\
(0.005)\end{array}$ & $\begin{array}{c}-0.030 * * * \\
(0.005)\end{array}$ & $\begin{array}{c}-0.010^{*} \\
(0.005)\end{array}$ \\
\hline $1=$ working part-time & & & $\begin{array}{c}0.036 * * * \\
(0.009)\end{array}$ & $\begin{array}{c}0.041 * * * \\
(0.009)\end{array}$ & $\begin{array}{c}0.052 * * * \\
(0.009)\end{array}$ \\
\hline \multicolumn{2}{|l|}{ Equivalized income } & & & & $\begin{array}{c}-0.000 * * * \\
(0.000)\end{array}$ \\
\hline Macro-region dummies & No & No & No & Yes & Yes \\
\hline Observations & 32,251 & 32,251 & 32,251 & 32,251 & 32,251 \\
\hline
\end{tabular}

Contributory schemes are unemployment, sickness and disability benefits. All models are estimated as probit regressions. The reported estimates are marginal effects computed at the average of all the control variables. 
Table 5: Recipiency of non-contributory benefits in the EU-SILC (2007)

\begin{tabular}{|c|c|c|c|c|c|}
\hline \multicolumn{6}{|c|}{ Dependent variable $=1$ if receiving any non-contributory benefit } \\
\hline & (1) & (2) & (3) & (4) & (5) \\
\hline \multicolumn{6}{|l|}{ Country of origin: } \\
\hline \multirow[t]{2}{*}{$1=\mathrm{EU} 25$} & 0.012 & 0.005 & 0.001 & 0.002 & -0.011 \\
\hline & $(0.022)$ & $(0.023)$ & $(0.023)$ & $(0.023)$ & $(0.023)$ \\
\hline \multirow[t]{2}{*}{$1=$ other countries } & $0.047 * * *$ & $0.034 * * *$ & $0.034 * * *$ & $0.042 * * *$ & 0.005 \\
\hline & $(0.012)$ & $(0.013)$ & $(0.013)$ & $(0.013)$ & $(0.013)$ \\
\hline \multicolumn{6}{|c|}{ Individual and household characteristics: } \\
\hline \multicolumn{2}{|l|}{ Years of schooling } & $\begin{array}{c}-0.005^{* * *} \\
(0.000)\end{array}$ & $\begin{array}{c}-0.005^{* * *} \\
(0.000)\end{array}$ & $\begin{array}{c}-0.005^{* * *} \\
(0.000)\end{array}$ & $\begin{array}{c}-0.004 * * * \\
(0.000)\end{array}$ \\
\hline Age & & $\begin{array}{c}0.013 * * * \\
(0.001)\end{array}$ & $\begin{array}{c}0.020 * * * \\
(0.002)\end{array}$ & $\begin{array}{c}0.020 * * * \\
(0.002)\end{array}$ & $\begin{array}{c}0.018 * * * \\
(0.002)\end{array}$ \\
\hline Age squared & & $\begin{array}{c}-0.000^{* * *} \\
(0.000)\end{array}$ & $\begin{array}{c}-0.000^{* * *} * \\
(0.000)\end{array}$ & $\begin{array}{c}-0.000^{* * * *} \\
(0.000)\end{array}$ & $\begin{array}{c}-0.000 * * * \\
(0.000)\end{array}$ \\
\hline $1=$ female & & $\begin{array}{l}-0.000 \\
(0.005)\end{array}$ & $\begin{array}{c}-0.022 * * * \\
(0.006)\end{array}$ & $\begin{array}{c}-0.020 * * * \\
(0.006)\end{array}$ & $\begin{array}{l}-0.010^{*} \\
(0.006)\end{array}$ \\
\hline HH size & & $\begin{array}{c}0.121 * * * \\
(0.006)\end{array}$ & $\begin{array}{c}0.118 * * * \\
(0.006)\end{array}$ & $\begin{array}{c}0.111^{* * * *} \\
(0.006)\end{array}$ & $\begin{array}{c}0.107 * * * \\
(0.006)\end{array}$ \\
\hline $1=$ single parent & & $\begin{array}{c}0.139 * * * \\
(0.018)\end{array}$ & $\begin{array}{c}0.140 * * * \\
(0.018)\end{array}$ & $\begin{array}{c}0.139 * * * \\
(0.018)\end{array}$ & $\begin{array}{c}0.105^{* * *} \\
(0.018)\end{array}$ \\
\hline Num. of kids $(<14)$ & & $\begin{array}{c}0.142 * * * \\
(0.004)\end{array}$ & $\begin{array}{c}0.140 * * * \\
(0.004)\end{array}$ & $\begin{array}{c}0.139 * * * \\
(0.004)\end{array}$ & $\begin{array}{c}0.144 * * * \\
(0.004)\end{array}$ \\
\hline \multicolumn{6}{|l|}{ Labour market status: } \\
\hline $1=$ working full time & & & $\begin{array}{c}-0.073 * * * \\
(0.007)\end{array}$ & $\begin{array}{c}-0.065^{* * *} * \\
(0.007)\end{array}$ & $\begin{array}{c}-0.011 \\
(0.007)\end{array}$ \\
\hline $1=$ working part-time & & & $\begin{array}{c}-0.028 * * \\
(0.011)\end{array}$ & $\begin{array}{c}-0.019^{*} \\
(0.011)\end{array}$ & $\begin{array}{c}0.010 \\
(0.012)\end{array}$ \\
\hline Equivalized income & & & & & $\begin{array}{c}-0.000 * * * \\
(0.000)\end{array}$ \\
\hline Macro-region dummies & No & No & No & Yes & Yes \\
\hline Observations & 32,251 & 32,251 & 32,251 & 32,251 & 32,251 \\
\hline
\end{tabular}

Non-contributory schemes are education-related allowances, family/children benefits, social exclusion provisions and housing allowances. All models are estimated as probit regressions. The reported estimates are marginal effects computed at the average of all the control variables. 
Table 6: Probability of ISEE submission - 2005

\begin{tabular}{|c|c|c|c|c|}
\hline \multicolumn{5}{|c|}{ Dependent variable $=1$ if a ISEE application has been submitted in 2005} \\
\hline & (1) & $(2)$ & (3) & (4) \\
\hline \multicolumn{5}{|l|}{ Country of origin: } \\
\hline $1=\mathrm{EU} 15$ & $\begin{array}{c}-0.023 * * * \\
(0.003)\end{array}$ & $\begin{array}{c}-0.026^{* * *} \\
(0.003)\end{array}$ & $\begin{array}{c}-0.021 * * * \\
(0.003)\end{array}$ & $\begin{array}{c}-0.029 * * * \\
(0.005)\end{array}$ \\
\hline $1=$ other European country & $\begin{array}{l}0.004 * \\
(0.002)\end{array}$ & $\begin{array}{l}-0.001 \\
(0.002)\end{array}$ & $\begin{array}{c}0.023 * * * \\
(0.002)\end{array}$ & $\begin{array}{c}0.084 * * * \\
(0.007)\end{array}$ \\
\hline $1=$ non-European country & $\begin{array}{c}0.015^{* * * *} \\
(0.002)\end{array}$ & $\begin{array}{c}0.004 * * \\
(0.002)\end{array}$ & $\begin{array}{c}0.027 * * * \\
(0.002)\end{array}$ & $\begin{array}{c}0.098 * * * \\
(0.005)\end{array}$ \\
\hline \multicolumn{5}{|c|}{ Unemployment rate (province level) and interaction with migrant: } \\
\hline Unemployment rate & & & & $\begin{array}{c}0.002 * * * \\
(0.000)\end{array}$ \\
\hline Unemployment rate $*(1=E U 15)$ & & & & $\begin{array}{l}0.001 * \\
(0.000)\end{array}$ \\
\hline Unemployment rate $*(1=$ oth. Europe $)$ & & & & $\begin{array}{c}-0.005 * * * \\
(0.000)\end{array}$ \\
\hline Unemployment rate $*(1=$ non-Europe $)$ & & & & $\begin{array}{c}-0.006 * * * \\
(0.000)\end{array}$ \\
\hline \multicolumn{5}{|l|}{ Individual characteristics: } \\
\hline $1=$ female & & $\begin{array}{c}-0.019 * * * \\
(0.001)\end{array}$ & $\begin{array}{c}-0.014 * * * \\
(0.001)\end{array}$ & $\begin{array}{c}-0.014 * * * \\
(0.001)\end{array}$ \\
\hline Age & & $\begin{array}{c}0.017 * * * \\
(0.000)\end{array}$ & $\begin{array}{c}0.015^{* * *} * \\
(0.000)\end{array}$ & $\begin{array}{c}0.015^{* * *} * \\
(0.000)\end{array}$ \\
\hline Age squared & & $\begin{array}{c}-0.000^{* * * *} \\
(0.000)\end{array}$ & $\begin{array}{c}-0.000 * * * \\
(0.000)\end{array}$ & $\begin{array}{c}-0.000 * * * \\
(0.000)\end{array}$ \\
\hline Regional dummies & No & No & Yes & Yes \\
\hline Observations & 407,154 & 407,154 & 407,154 & 407,154 \\
\hline
\end{tabular}

All models are estimated as probit regressions. The reported estimates are marginal effects computed at the average of all the control variables. 
Table 7: Probability of ISEE submission by type of program - 2005

\begin{tabular}{|c|c|c|c|c|}
\hline \multicolumn{5}{|c|}{ Dependent variable $=1$ if a ISEE application has been submitted in 2005} \\
\hline & $\begin{array}{l}\text { Family } \\
\text { (1) }\end{array}$ & $\begin{array}{l}\text { Education } \\
\text { (2) }\end{array}$ & $\begin{array}{l}\text { Health } \\
\text { (3) }\end{array}$ & $\begin{array}{l}\text { Other } \\
(4)\end{array}$ \\
\hline \multicolumn{5}{|l|}{ Country of origin: } \\
\hline $1=\mathrm{EU} 15$ & $\begin{array}{c}-0.002 * * * \\
(0.001)\end{array}$ & $\begin{array}{c}-0.013 * * * \\
(0.002)\end{array}$ & $\begin{array}{c}-0.000 \\
(0.000)\end{array}$ & $\begin{array}{c}-0.011 * * * \\
(0.002)\end{array}$ \\
\hline $1=$ other European country & $\begin{array}{c}0.000 \\
(0.001)\end{array}$ & $\begin{array}{c}0.010 * * * \\
(0.002)\end{array}$ & $\begin{array}{l}-0.000 \\
(0.000)\end{array}$ & $\begin{array}{c}0.020 * * * \\
(0.002)\end{array}$ \\
\hline $1=$ non-European country & $\begin{array}{c}0.003^{* * *} * \\
(0.001)\end{array}$ & $\begin{array}{c}0.003 * * * \\
(0.001)\end{array}$ & $\begin{array}{l}-0.000 \\
(0.000)\end{array}$ & $\begin{array}{c}0.024 * * * \\
(0.002)\end{array}$ \\
\hline \multicolumn{5}{|l|}{ Individual characteristics: } \\
\hline $1=$ female & $\begin{array}{c}0.000 \\
(0.000)\end{array}$ & $\begin{array}{c}-0.011 * * * \\
(0.001)\end{array}$ & $\begin{array}{c}-0.001 * * * \\
(0.000)\end{array}$ & $\begin{array}{c}-0.010^{* * *} \\
(0.001)\end{array}$ \\
\hline Age & $\begin{array}{c}0.004 * * * \\
(0.000)\end{array}$ & $\begin{array}{c}0.013 * * * \\
(0.000)\end{array}$ & $\begin{array}{c}0.000 * * * \\
(0.000)\end{array}$ & $\begin{array}{c}0.007 * * * \\
(0.000)\end{array}$ \\
\hline Age squared & $\begin{array}{c}-0.000 * * * \\
(0.000)\end{array}$ & $\begin{array}{c}-0.000 * * * \\
(0.000)\end{array}$ & $\begin{array}{c}-0.000 * * * \\
(0.000)\end{array}$ & $\begin{array}{c}-0.000 * * * \\
(0.000)\end{array}$ \\
\hline Regional dummies & Yes & Yes & Yes & Yes \\
\hline Observations & 407,154 & 407,154 & 407,154 & 407,154 \\
\hline
\end{tabular}


Table 8: Poisson regression for the number of programs requests with ISEE

\begin{tabular}{|c|c|c|c|c|c|}
\hline \multicolumn{6}{|c|}{ Dependent variable $=$ num. of welfare applications in 2005} \\
\hline \multicolumn{6}{|l|}{ Country of origin: } \\
\hline $1=\mathrm{EU} 15$ & $\begin{array}{l}-0.000 \\
(0.038)\end{array}$ & $\begin{array}{c}0.024 \\
(0.038)\end{array}$ & $\begin{array}{c}0.023 \\
(0.038)\end{array}$ & $\begin{array}{c}0.010 \\
(0.038)\end{array}$ & $\begin{array}{c}0.011 \\
(0.038)\end{array}$ \\
\hline $1=$ other European country & $\begin{array}{c}-0.136^{* * * *} \\
(0.022)\end{array}$ & $\begin{array}{c}-0.121 * * * \\
(0.022)\end{array}$ & $\begin{array}{c}-0.128 * * * \\
(0.022)\end{array}$ & $\begin{array}{l}-0.024 \\
(0.022)\end{array}$ & $\begin{array}{l}-0.014 \\
(0.022)\end{array}$ \\
\hline $1=$ other non-European country & $\begin{array}{c}-0.190 * * * \\
(0.017)\end{array}$ & $\begin{array}{c}-0.194 * * * \\
(0.017)\end{array}$ & $\begin{array}{c}-0.201 * * * \\
(0.017)\end{array}$ & $\begin{array}{c}-0.086^{* * *} \\
(0.018)\end{array}$ & $\begin{array}{c}-0.076 * * * \\
(0.018)\end{array}$ \\
\hline \multicolumn{6}{|l|}{ Individual characteristics: } \\
\hline $1=$ female & & $\begin{array}{c}-0.065 * * * \\
(0.008)\end{array}$ & $\begin{array}{c}-0.047 * * * \\
(0.009)\end{array}$ & $\begin{array}{c}-0.025^{* * *} * \\
(0.009)\end{array}$ & $\begin{array}{c}-0.026 * * * \\
(0.009)\end{array}$ \\
\hline Age & & $\begin{array}{c}0.004 \\
(0.003)\end{array}$ & $\begin{array}{l}-0.000 \\
(0.003)\end{array}$ & $\begin{array}{l}-0.006^{*} \\
(0.003)\end{array}$ & $\begin{array}{l}-0.004 \\
(0.003)\end{array}$ \\
\hline Age squared & & $\begin{array}{l}-0.000 \\
(0.000)\end{array}$ & $\begin{array}{c}0.000 \\
(0.000)\end{array}$ & $\begin{array}{l}0.000 * * \\
(0.000)\end{array}$ & $\begin{array}{l}0.000^{*} \\
(0.000)\end{array}$ \\
\hline \multicolumn{6}{|l|}{ Household characteristics: } \\
\hline HH size & & $\begin{array}{c}0.076^{* * *} * \\
(0.003)\end{array}$ & $\begin{array}{c}0.077 * * * \\
(0.003)\end{array}$ & $\begin{array}{c}0.068 * * * \\
(0.003)\end{array}$ & $\begin{array}{c}0.066^{* * * *} \\
(0.003)\end{array}$ \\
\hline $1=$ single parent & & $\begin{array}{l}0.061 * * * \\
(0.016)\end{array}$ & $\begin{array}{c}0.058 * * * \\
(0.016)\end{array}$ & $\begin{array}{l}0.079 * * * \\
(0.016)\end{array}$ & $\begin{array}{c}0.087 * * * \\
(0.016)\end{array}$ \\
\hline $1=$ working parent & & $\begin{array}{c}-0.107 * * * \\
(0.012)\end{array}$ & $\begin{array}{c}-0.125^{* * *} \\
(0.013)\end{array}$ & $\begin{array}{c}-0.046^{* * *} \\
(0.013)\end{array}$ & $\begin{array}{c}-0.053 * * * \\
(0.013)\end{array}$ \\
\hline $1=$ employed & & & $\begin{array}{c}0.055^{* * * *} \\
(0.009)\end{array}$ & $\begin{array}{c}0.073 * * * \\
(0.009)\end{array}$ & $\begin{array}{c}0.065^{* * *} * \\
(0.009)\end{array}$ \\
\hline $\begin{array}{l}\text { Equivalized income } \\
\text { and wealth }\end{array}$ & & & & & $\begin{array}{c}0.000 \\
(0.000)\end{array}$ \\
\hline Regional dummies & No & No & No & Yes & Yes \\
\hline Observations & 32,605 & 32,605 & 32,605 & 32,605 & 32,605 \\
\hline
\end{tabular}

